\title{
Firewood Resource Management in Different Landscapes in NW Patagonia
}

\author{
Daniela V. Morales ${ }^{1}$, Soledad Molares ${ }^{1}$ and Ana H. Ladio ${ }^{2 *}$ \\ ${ }^{1}$ Centro de Investigación Esquel de Montaña y Estepa patagónica, CONICET Universidad Nacional de la Patagonia San \\ Juan Bosco, Esquel, Argentina, ${ }^{2}$ Instituto Nacional de Investigaciones en Biodiversidad y Medio Ambiente, CONICET \\ Universidad Nacional del Comahue, S.C. de Bariloche, Argentina
}

OPEN ACCESS

Edited by:

Urs Feller,

University of Bern, Switzerland

Reviewed by:

Andrey S. Zaitsev,

Justus Liebig Universität Gießen,

Germany

Milton Kanashiro,

Embrapa Amazonia Oriental (Embrapa

Easter Amazon), Brazil

*Correspondence:

Ana H. Ladio

ahladio@gmail.com

Specialty section:

This article was submitted to Agroecology and Land Use Systems,

a section of the journal

Frontiers in Ecology and Evolution

Received: 23 June 2017 Accepted: 01 September 2017

Published: 15 September 2017

Citation:

Morales DV, Molares S and Ladio AH

(2017) Firewood Resource

Management in Different Landscapes in NW Patagonia.

Front. Ecol. Evol. 5:111. doi: 10.3389/fevo.2017.00111
Ecosystems, their components, processes and functions are all subject to management by human populations, with the purpose of adapting the environments to make them more habitable and ensuring the availability and continuity of subsistence resources. Although a lot of work has been carried out on resources of alimentary or medicinal interest, little has been done on associating processes of domestication with firewood extraction, a practice considered to be destructive of the environment. In the arid steppe of NW Patagonia, inhabited and managed for different purposes for a long time by Mapuche-Tehuelche communities, the gathering of combustible plant species has up to the present time played a crucial role in cooking and heating, and work is required to achieve sustainability of this resource. In this study we evaluate whether environments with less landscape domestication are more intensively used for firewood gathering. Using an ethnobiological approach, information was obtained through participant observation, interviews and free listing. The data were examined using both qualitative and quantitative approaches. Twenty-eight firewood species are gathered, both native (75\%) and exotic (25\%). The supply of firewood mainly depends on gathering from the domesticated (10 species), semi-domesticated (17 species) and low human intervention landscapes (17 species). In contrast to our hypothesis, average use intensity is similar in all these landscapes despite their different levels of domestication. That is, the different areas are taken advantage of in a complementary manner in order to satisfy the domestic demand for firewood. Neither do biogeographic origin or utilitarian versatility of collected plants vary significantly between the different landscape levels of domestication. Our results show that human landscape domestication for the provision of firewood seems to be a socio-cultural resilient practice, and shed new light on the role of culture in resource management. This approach may offer new tools for the development of firewood and cultural landscape management, and conservation planning.

Keywords: gathering practices, socio-cultural resilience, complementarity, management

\section{INTRODUCTION}

Ecosystems, their components, processes and functions are all subject to transformation or management by local populations. Traditional ecological management is understood to be a set of interventions and transformations which are the result of community decisions regarding the natural and artificial systems, with the explicit purpose of adapting the landscape to make it more 
habitable and ensuring the availability of certain natural resources (Casas et al., 2014). According to Toledo et al. (2003), resource management is an adaptive response to the uncertainty of their availability. It is part of the human desire to domesticate or control whatever is affected by this condition of uncertainty, so as to ensure the continuation of social and cultural life (Blancas et al., 2014).

The subject of landscapes as biocultural systems has been studied widely over recent years (Berkes et al., 2000; Miller and Davidson-Hunt, 2010; Casas et al., 2014; Lins Neto et al., 2014). They are considered as physical spaces which reflect the use, values, learning and cosmovisions of the societies inhabiting them over time (Capparelli et al., 2011; Castro et al., 2012), and they also acquire a symbolic character as they are accorded significance by the different cultures (Greider and Garkovich, 1994; Boillat et al., 2013; Fernández-Llamazares et al., 2016).

The landscapes have been, and still are, constantly changed by their human inhabitants, leading to processes of domestication through both individual and collective subsistence practices which are reproduced and recreated in a dynamic way. This leads to socio-environmental constructions impregnated with everyday experience, in a permanent state of adaptation to the surroundings and their changing conditions (Berkes and Davidson-Hunt, 2006; Haber, 2006; Kareiva et al., 2007; Castro et al., 2012; Lema, 2014). It is currently considered that the study of these practices in contexts that have undergone processes of change represents a key way of understanding the value of resources and their potential conservation (Washington, 2013; Blancas et al., 2014).

Local strategies for managing certain space-time resources depend on perception of which resources are useful and can be taken advantage of and preserved, and which are not, according to the necessities and perspectives arising over time among the population (Blancas et al., 2014). Shaanker et al. (2003) highlight that locals' ecological knowledge may have important implications for the long term conservation of plant resources, and that communities with a greater degree of this knowledge might be more "prudent" in their use of the environment, through adoption of less destructive harvesting practices, particularly when economic interests are affected, and even when being "prudent" implies poorer short term returns.

The study of the body of fuelwood knowledge which forms part of the accumulative cultural heritage of local communities, referred to conceptually as traditional ecological knowledge (TEK) (Berkes et al., 2000), may contribute to the construction of perspectives on the sustainable management of these ecosystems. This involves in-depth study of the knowledge and practices associated with use of the environment, which are related to the maintenance of ecological cycles, and therefore ensure sustainability, thus making possible the coexistence and even the evolution of inhabitants along with their natural resources (Berkes et al., 2000; Shaanker et al., 2003; Berkes, 2004; Tiwari et al., 2010). Despite the progress made in this subject with regard to the use of firewood (Cardoso et al., 2012, 2015; Arre et al., 2015; Morales et al., 2017), the processes associated with domestication of the arid cultural landscape leading to the promotion and supply of these scarce resources are still unknown. The studies refer mainly to firewood extraction as a destructive practice that shows little care for the environment or resource renewal (Tabuti, 2007).

Among the practices of anthropization of the environment, the ex and in situ management of vegetation (Casas et al., 2007, 2008, 2014; Lins Neto et al., 2014), control of ecological succession, diversion of watercourses and the gathering of useful plants (Davidson-Hunt and Berkes, 2003; Molares and Ladio, 2009; Pirondo and Keller, 2014), have been mentioned as strategies which increase the supply of species of interest and reduce the uncertainty of their availability throughout the year and in succeeding years (Barrera-Bassols and Toledo, 2005; Molares and Ladio, 2009). For example, taking advantage of ruderal and exotic species that appear rapidly on land where clearings have been produced by disturbances of moderate intensity is a practice shared by many cultures (Molares and Ladio, 2014).

The species diversity constructed through different management practices may be taken advantage of in different ways, utilitarian versatility being considered as the sum of the different uses presented by a certain resource. It has been found that the species with highest use consensus in these societies often present high utilitarian versatility, a pattern based on profound knowledge of the best-known species, which promotes caring attitudes, since the people value the potential of the species in a holistic way (Richeri et al., 2013). Studies performed on medicinal plants have shown that plants native to a certain place generally offer greater use diversity than exotic species, due to the longer period of time they have been in contact with local populations (Molares and Ladio, 2009).

Since ancient times indigenous communities in Patagonia have bonded with the resources in their environment, which has not only allowed them to develop a deep knowledge of nature, but has also favored the creation of diverse landscapes with different levels of domestication (Ladio and Molares, 2014; Sedrez dos Reis et al., 2014). These communities have viewed nature as a fundamental part of their life system. In particular, the Andean environment, across its entire altitudinal gradient, is taken advantage of as a source of natural resources through different gathering practices, although practices tending toward tolerance, facilitation and promotion are also observed (Ladio and Molares, 2014), generating a gradient/continuum of landscapes with different levels of human intervention. These spaces were, and still are, valued differentially according to their vegetation and geomorphological characteristics, as well as their utilitarian and symbolic attributes (Ladio and Lozada, 2003, 2004; Ladio et al., 2007).

The gathering of woody species for fire is a subject of great socioeconomic relevance on a global level (Tabuti et al., 2003; Chettri and Sharma, 2007; Ramos et al., 2008) and as an area of study, considering the cultural value of heating by firewood, the severity of winter at this latitude, the scarcity of available petroleum-based alternatives, and their high cost (Cardoso et al., 2012). As a result, most households, and the rural or semi-rural ones in particular, depend principally on plants for cooking and heating (Cardoso et al., 2012; Arre et al., 2015). Recent ethnobotanical studies in Patagonia have documented 
consumption patterns of firewood species, the attributes of the wood, and preferences shown by locals, oriented mainly toward native species (Cardoso et al., 2012, 2013, 2015; Arre et al., 2015) and the new practices employed to counteract scarcity of the firewood resource, such as the use of exotic species of more or less recent appearance in the region (Cardoso et al., 2017). This evidence reflects constant processes of hybridization of knowledge, which make possible the incorporation of new woody elements to compensate for deficiencies (Cardoso and Ladio, 2011).

The objectives of this work were to analyze the gathering patterns of firewood plants and their relationship with the different domesticated landscapes that form part of daily life in two rural communities of the Patagonian steppe. Our questions are: (1) whether environments with a lower level of landscape domestication are used more intensively for firewood gathering, in terms of species richness and use consensus. (2) whether in these environments with a lower level of landscape domestication a higher proportion of native species are gathered, and a higher number of species that were used in the past. (3) whether in these environments with a lower level of landscape domestication the woody species are used in a more versatile way.

\section{MATERIALS AND METHODS}

\section{Study Area}

The study area takes in the communities of Gualjaina $\left(42^{\circ} 4^{\prime} \mathrm{S}\right.$ and $\left.70^{\circ} 32^{\prime} \mathrm{W}\right)$ and Paraje Costa del Lepá $\left(42^{\circ} 34^{\prime} \mathrm{S}\right.$ and $\left.71^{\circ} 03^{\prime} \mathrm{W}\right)$, in the northwest of Chubut province, Argentina (Figure 1). They are neighboring communities, approximately $15 \mathrm{~km}$ apart, and have close links in terms of family, lifestyle and work, among other factors. The area is located in the Central Plateau Region, in the Lepá and Gualjaina river basins, at an altitude of between 545 and 760 m.a.s.l.

These communities are located in environments dominated by grass-shrub steppe. The predominant species are Mulynum spinosum (Cav). Pers., Senecio filaginoides DC., Nassauvia axillaris (Lag. ex Lindl.) D. Don., Berberis mycrophilla G. Forst., and Schinus johnstonii F.A. Barkley. This area corresponds to the phytogeographical region of Patagonian Province, Central District (Cabrera, 1976).

The climate is dry and cool. Annual average precipitation of $119 \mathrm{~mm}$, mainly concentrated between May and September, with annual temperatures of $17.5^{\circ} \mathrm{C}$ in summer and $2.6^{\circ} \mathrm{C}$ in winter; dominant winds are from the west (Mereb, 1990).

Gualjaina has an estimated population of 1183 inhabitants and a total population of 2,500 people including the 17 smaller communities (one of these is Costa de Lepá) that have formed close to it, and it covers an area of ca. $2,870 \mathrm{~km}^{2}$, based on the population census of 2010 (Instituto Nacional de Estadística y Censos, 2010). In this region a proportion of the population live in the town, while other residents are distributed along the edges of rivers or in rural areas. Most people are descendants of Mapuches and Creoles (ECPI, 2007). There are some institutions in the communities, such as police, hospital, school and some churches (Catholic and Evangelical). In addition, some national institutions from outside the community work in the area (National Institute for Agricultural Technology; Development Corporation of Chubut province). They have provided technical assistance and exotic plant seeds with agricultural uses. The main economic activity is based on livestock breeding and to a lesser degree, agriculture, handcraft sales, commerce, tourism, and some people are supported by social assistance from the state. Firewood is the most significant fuel in these communities, many of which employ it for domestic use, as they have no access to gas.

\section{Data Collection}

Fieldwork for this study was carried out between February and November 2015. A total of 33 household heads consented to participate in the interviews. Each person was asked to sign the Free and Clarified Consent Form according to the Code of Ethics of the International Society of Ethnobiology (ISE, 2006).

The adult population was composed of men and women ranging in age from 30 to 90 , with a mean age of 59.8. The informants were selected at random, each one representing a household unit. Free listing was used to determine the composition and species richness of firewood plants known by

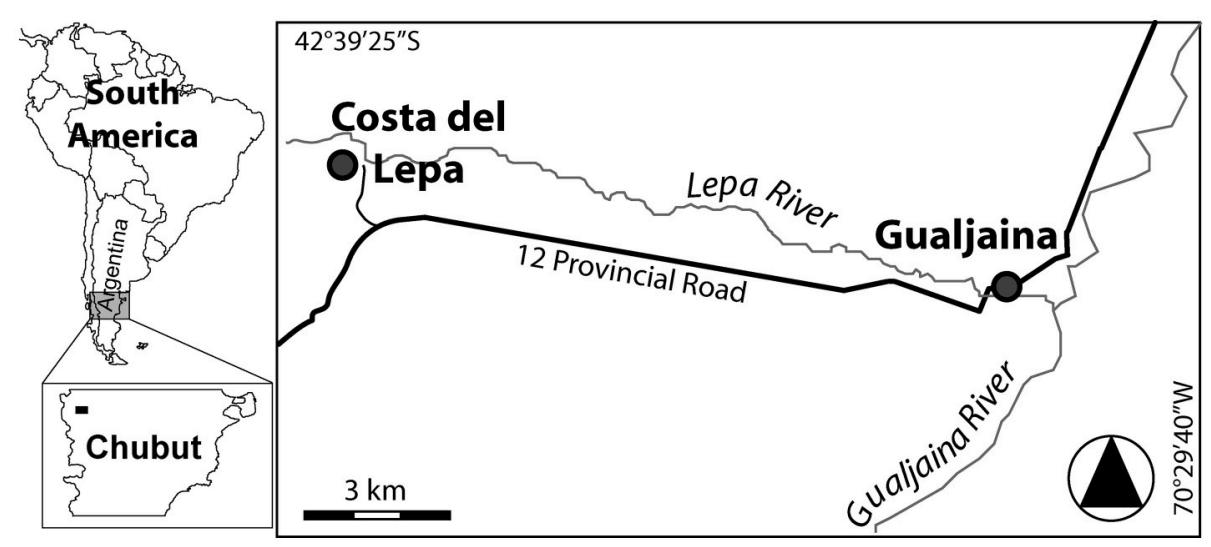

FIGURE 1 | Location of the study area in NW Chubut province, Argentina. 
each informant (Alburquerque et al., 2010). In addition, open and semi-structured interviews were carried out in order to comprehend the landscape dynamic used to obtain firewood plants. We asked the local inhabitants about places for gathering firewood species (i.e., scrubland, cultivated land, areas close to water bodies). Furthermore, informants were consulted as to any additional uses of the firewood species named, strategies for acquiring them and the continuity of use of the species. Analysis of use continuity was based on the methodology proposed by Fernández-Llamazares et al. (2016); participants were asked whether each firewood species mentioned had been used in the past and up to the present, or if it was used only in the past, or only in the present. The point of reference used to represent the past was the informant's childhood.

Data were supplemented using other ethnobotanical techniques, such as participant observation, in-depth interviews and field excursions with key informants in order to collect botanical material of the species cited in the interviews (Guber, 2006). Samples of plants were herborized and placed in the Esquel Mountain and Patagonian Steppe Research Center. The botanical reference material was identified according to Correa $(1971,1978,1984)$ and its scientific names were updated following Zuloaga and Morrone (1999) and International Plant Names Index (www.ipni.org).

\section{Data Analysis}

Composition and richness of species and botanical families were estimated using the total number of species mentioned by the Mapuche informants.

The biogeographic origin of species was classified according to the Darwinion Institute catalog of vascular plants (Zuloaga and Morrone, 1999) and the following were considered as etic categories: native to Patagonia (indigenous species that grow approximately from $37^{\circ} \mathrm{S}$ southward) and exotic to Patagonia.

Use consensus (UC) was obtained considering the frequency of use citations for each species in the total population. It was calculated by dividing the number of informants (n) who used the species (i) by the total number of informants interviewed $(N$ $=33) \times 100,(\mathrm{ni} / \mathrm{N} \times 100)($ Molares and Ladio, 2012). This index is used as an indirect measure of the importance of use of cited species.

The versatility of use of the species was estimated using the index: UVi $=\sum$ UVsi/ni (Phillips and Gentry, 1993), where UVsi is the number of uses registered by informant $i$ for species $\mathrm{s}$, and ni is the number of people who mention species i. The values obtained were put into two categories: (1). Fuel use only; (2). Fuel use plus one or more additional uses (i.e., construction, fodder, medicinal, edible).

Acquisition strategies of firewood resources were classified etically as: gathering, purchase, exchange or state subsidies.

The landscape used for gathering wood was analyzed considering the different management processes used by the population and also the different signs of domestication. These local observations of the Mapuche landscape were then grouped into several etic categories listed further: Landscape with low human intervention: this was defined as the environment with lowest human influence or management (i.e., hills and plains with mainly grasses and low bushes, with scattered clumps of native shrubs approximately $1.50 \mathrm{~m}$ in height, all intertwined; extensive livestock grazing; no separation of areas or zoning of pastureland; no movement of land, or irrigation, and only scarce to moderate quantities of dung; located at a distance of no less than $3 \mathrm{~km}$ from human settlements). Semidomestic landscape: moderate human intervention (i.e., more signs and dung from animals than previous environment, and areas with bare soil; includes areas next to rivers, with small clumps of exotic species of Salix sp.; few, widely separated irrigation canals; temporary infrastructures such as cattle sheds; shelter from wind for the animals, constructed with corrugated iron, poles and tethering posts). Domestic landscape: has undergone the highest level of human intervention (i.e., around dwellings, where outbuildings are situated, corrals, gardens and other cultivated spaces such as vegetable gardens or small fruit and vegetable farms). The continuity of use of each woody species was categorized as: current use (i.e., the person has used it within the last year), past use (i.e., the species mentioned was used only in their infancy); current-past use (i.e., the same species continues to be used from the informant's infancy up to the present time).

For general analysis, the total richness of native and exotic species was compared using a binomial test $(p<0.05)$, and use consensus was calculated with the Mann Whitney $U$-test $(p<$ $0.05)$.

The richness of firewood species in the different types of landscape was compared by means of the Chi-squared test $(p<$ 0.05 ), and to compare the biogeographic origin and use versatility of the species gathered in each type of landscape the binomial test was used $(p<0.05)$. Species similarity between environments with different levels of domestication was analyzed using the Jaccard index $(J \mathrm{~J}: \mathrm{c} /(\mathrm{a}+\mathrm{b}+\mathrm{c}) \times 100)$, where $\mathrm{c}$ is the number of species common to two environments, $a$ is the number of unique species in environment $\mathrm{A}$, and $\mathrm{b}$ is the number of unique species in environment B (Höft et al., 1999).

The UC of the species was compared for different types of landscape, according to the following categories: biogeographic origin, use versatility and continuity of use by means of the non-parametric Kruskall Wallis test $(p<0.05)$. In addition, for each landscape comparisons were made of UC in relation to versatility, using the Mann Whitney $U$-test $(p<0.05)$.Species richness was compared between the continuity of use classes using the Chi-squared test $(p<0.05)$.

In addition, a multinomial logistic regression analysis was carried out with the SPSS 22.0 program in order to complement the information and obtain a model to explain how the proportion of plants varies between the different levels of landscape domestication (dependent variable category) according to their biogeographic origin and use versatility (independent variable category) (Chan, 2005; Ladio and Molares, 2013). In this analysis we excluded the species obtained through purchase or subsidies (i.e., Nothofagus antarctica, Pinus spp.) and the variables (i.e., life form, continuity of use) that do not register as significant in the model. In this kind of regression, tendencies are established according to the categories under comparison; in this case, the domestic landscape. A description of the variables in the model and the distribution of all cases are shown in Table 2. 
The model was found to be significant $(p<0.05)$. Calculations of the odds ratios (i.e., the probability of an event happening) are shown in Table 3 by means of $\mathrm{e}^{\text {beta }}=\operatorname{Exp}$ (B) (Chan, 2005; Ladio and Molares, 2013).

\section{RESULTS}

\section{The Role of Firewood in the Lives of Costa de Lepá and Gualjaina Inhabitants}

Firewood plants provide the main fuel for heating and cooking for almost all households in Gualjaina and Costa del Lepá (100\% of informants). The gathering and use of plants is an activity carried out by both men and women, all year round. Collection patterns consist of gathering ( $97 \%$ of informants) a mixture of dead and green wood for the purpose of long-lasting fires, or fallen pieces of wood in open wild areas, and pruned branches from forest plantations. The firewood is then transported in bundles carried on the shoulders, or the load is carried by an animal or by human-powered carts (Figure 2).

Approximately half the community complement firewood gathering with purchase (48\%), and they mainly buy firewood from Sub-Antarctic forest such as $N$. antarctica. To a lesser extent $(15 \%)$, locals are aided by government firewood programs called "the heat program" which provide home heating assistance in the form of $6 \mathrm{~m}^{3}$ of firewood in winter, composed mainly of $N$. antarctica, Pinus spp., Salix sp. and Populus alba. The exchange of firewood for animals (3\%) also takes place, both within the community and with neighboring communities.

In addition to the above, in some situations where wood is limited other fuel-types such as liquefied Petroleum Gas (LPG) and animal by-products, including dung from cows and sheep, are used. In general, people reported using LPG (82\%) only for cooking or heating up water, due to its elevated cost.

The communities convey the important role that firewood plays in their culture; they do not simply view it in terms of meeting energy needs. The cooking stoves provide the highly appreciated space heating that allows families to sit around the fire and socialize. As well as this, the taste of some traditional meals is associated with the selection of firewood used in its preparation. For example, the embers of Nassauvia axillaris are used for cooking bread. In addition, according to informants,

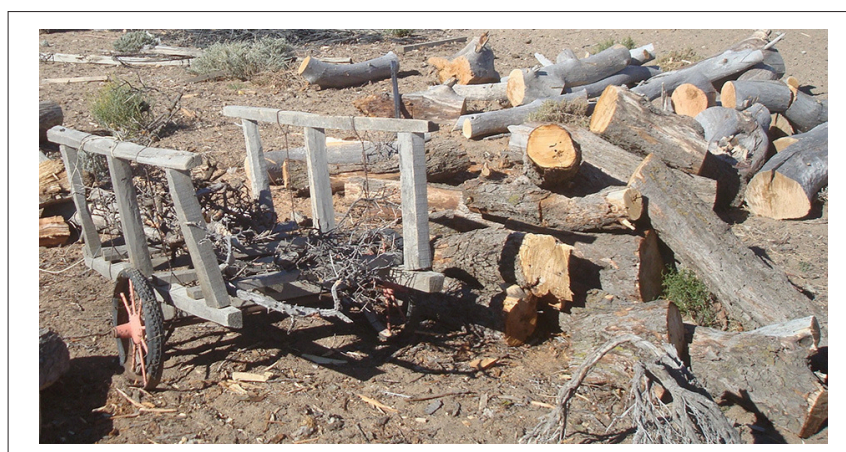

FIGURE 2 | Gathering firewood of Salix sp., P. alba and a mixture of branches from different trees with human-powered carts in Costa del Lepá, Chubut. heating a home with firewood is healthier than using other forms of heating. However, for most informants the supply of firewood now and in the future is a constant source of worry, and they feel responsible for finding alternatives due to the current scarcity. As some locals commented: "the people always used to go out to collect firewood, now you don't see it so much..."(D.A). "It's good that you folk who come from outside tell us what can be done to improve the situation, things that we don't realize..."(E.O).

\section{The Gathering of Native and Exotic Firewood Plants}

Plant composition: Locals gather a total of 28 firewood species, belonging to 24 genera, and grouped into 14 families (Table 1), of which Asteraceae (5 species) and Salicaceae (4 species) are the most collected. The most frequently collected species are the native S. johnstonii (use consensus of 78.8\%) and N. axillaris (54.5\%), and the exotic Salix sp. (87.9\%) and P. alba (54.5\%) (Table 1). As expected, considering biogeographic origin and not taking into account the gathering environments they come from, or their different levels of domestication, the total richness of plants used as firewood was higher for native species $(75 \%$, 22 species), while exotic species accounted for $25 \%$ (6 species) (Binomial test, $p=0.02$ ). However, it is notable that with respect to use consensus, inhabitants appear to use exotic species (27.3\% $\pm 14.6)$ more than native species $(18.2 \% \pm 4)$, although this difference is not significant (Mann Whitney $U$-test, $p=0.97$ ).

\section{Domesticated Landscapes and Firewood Gathering Species Richness According to the Level of Landscape Domestication}

The richness of firewood species is not higher in environments with less domestication, and does not vary significantly between different landscape categories (Chi-squared test $p=0.328$ ) (Figure 3). The richness found in domestic landscapes is represented by 10 species, whereas in the semi-domestic and low intervention landscapes it is composed of 17 species.

With regard to the similarity of woody species between different domesticated landscapes, the highest values were obtained for the low domestication and semidomestic landscapes (50\% of the species). The domestic and semidomestic landscapes, meanwhile, showed only $13 \%$ similarity. No similarity whatsoever was found between the domestic and low intervention landscapes (0\%).

Informants mentioned (19\% of cites) that the domesticated landscapes, which have undergone most human intervention, are taken advantage of for both native and exotic firewood species (Binomial test, $p=0.75)$, of which a high proportion $(60 \%, 6$ species) are cultivated exotic species, while the remainder (40\%) are native species (Figure 3). The most frequent species are $P$. alba and Salix sp.

The semi-domestic areas, made up of river valleys that run through the communities (rivers Gualjaina and Lepá, Figure 1) together with the wetlands (flood meadows and water holes), also represent areas recognized for their provision of firewood. Not only do locals find wood here for cutting, but also driftwood from 
TABLE 1 | Firewood species used in the rural communities of Costa del Lepá and Gualjaina, in the Patagonia steppe.

\begin{tabular}{|c|c|c|c|c|c|c|}
\hline Scientific name & Vernacular name & Family & Origin & UC (\%) & $\begin{array}{l}\text { Firewood acquisition } \\
\text { strategies }\end{array}$ & Degree of domestication \\
\hline Salix sp. & Sauce & Salicaceae & $E$ & 87.9 & $\begin{array}{l}\text { Gathering. Purchase. } \\
\text { Firewood programs. } \\
\text { Exchange. }\end{array}$ & Semi-domestic. Domestic \\
\hline Schinus johnstonii F.A. Barkley. & Molle & Anacardiaceae & $\mathrm{N}$ & 78.8 & Gathering. Exchange. & $\begin{array}{l}\text { Low degree of human influence. } \\
\text { Semi-domestic. }\end{array}$ \\
\hline Populus alba L. & Alamo plateado & Salicaceae & $E$ & 54.5 & $\begin{array}{l}\text { Gathering. Purchase. } \\
\text { Firewood programs. } \\
\text { Exchange. }\end{array}$ & Semi-domestic. Domestic. \\
\hline $\begin{array}{l}\text { Nassauvia axillaris (Lag. ex Lindl.) D. } \\
\text { Don }\end{array}$ & Uña de gato & Asteraceae & $\mathrm{N}$ & 54.5 & Gathering. Exchange. & $\begin{array}{l}\text { Low degree of human influence. } \\
\text { Semi-domestic. }\end{array}$ \\
\hline $\begin{array}{l}\text { Nothofagus antarctica* (G. Forst.) } \\
\text { Oerst. }\end{array}$ & Ñire & Nothofagaceae & $\mathrm{N}$ & 45.5 & $\begin{array}{l}\text { Purchase. Firewood } \\
\text { programs. }\end{array}$ & \\
\hline $\begin{array}{l}\text { Corynabutilon bicolor (Phil. ex K. } \\
\text { Schum.) Kearney }\end{array}$ & Monte moro & Malvaceae & $\mathrm{N}$ & 33.3 & Gathering. & $\begin{array}{l}\text { Low degree of human influence. } \\
\text { Semi-domestic. }\end{array}$ \\
\hline Lycium sp. & Monte negro & Solanaceae & $\mathrm{N}$ & 27.3 & Gathering. & $\begin{array}{l}\text { Low degree of human influence. } \\
\text { Semi-domestic. }\end{array}$ \\
\hline Berberis mycrophylla G. Forst. & Calafate & Berberidaceae & $\mathrm{N}$ & 27.3 & Gathering. Exchange. & $\begin{array}{l}\text { Low degree of human influence. } \\
\text { Semi-domestic. }\end{array}$ \\
\hline Senecio filaginoides DC & Charcao & Asteraceae & $\mathrm{N}$ & 24.2 & Gathering. Exchange. & $\begin{array}{l}\text { Low degree of human influence. } \\
\text { Semi-domestic. Domestic. }\end{array}$ \\
\hline $\begin{array}{l}\text { Stillingia patagonica (Speg.) Pax and } \\
\text { K. Hoffm. }\end{array}$ & Mata perro & Euphorbiaceae & $\mathrm{N}$ & 24.2 & Gathering. & $\begin{array}{l}\text { Low degree of human influence. } \\
\text { Semi-domestic. }\end{array}$ \\
\hline $\begin{array}{l}\text { Ochetophila trinervis (Gillies ex Hook. } \\
\text { and Arn.) }\end{array}$ & Chacai & Rhamnaceae & $\mathrm{N}$ & 21.2 & Gathering. & $\begin{array}{l}\text { Low degree of human influence. } \\
\text { Semi-domestic. }\end{array}$ \\
\hline $\begin{array}{l}\text { Baccharis salicifolia (Ruiz and Pav.) } \\
\text { Pers. }\end{array}$ & Chilca & Asteraceae & $\mathrm{N}$ & 18.2 & Gathering. & $\begin{array}{l}\text { Low degree of human influence. } \\
\text { Semi-domestic. }\end{array}$ \\
\hline Chuquiraga avellanedae Lorentz & Trallao & Asteraceae & $\mathrm{N}$ & 18.2 & Gathering. & $\begin{array}{l}\text { Low degree of human influence. } \\
\text { Semi-domestic. Domestic. }\end{array}$ \\
\hline $\begin{array}{l}\text { Prosopis denudans var. patagonica } \\
\text { Benth. (Speg.) Burkart }\end{array}$ & Algarrobillo & Fabaceae & $\mathrm{N}$ & 15.2 & Gathering. & $\begin{array}{l}\text { Low degree of human influence. } \\
\text { Semi-domestic. }\end{array}$ \\
\hline Retanilla patagonica (Speg.) Tortosa & Barba chivo & Rhamnaceae & $\mathrm{N}$ & 15.2 & Gathering. & $\begin{array}{l}\text { Low degree of human influence. } \\
\text { Semi-domestic. }\end{array}$ \\
\hline Prunus cerasus L. & Guindo & Rosaceae & $E$ & 9.1 & Gathering crop residues. & Domestic. \\
\hline Salix humboldtiana Willd. & Sauce común & Salicaceae & $\mathrm{N}$ & 9.1 & $\begin{array}{l}\text { Gathering. Purchase. } \\
\text { Firewood programs. }\end{array}$ & Semi-domestic. Domestic. \\
\hline Adesmia volckmanni Phil. & Mamuel choique & Fabaceae & $\mathrm{N}$ & 6.1 & Gathering. Exchange. & $\begin{array}{l}\text { Low degree of human influence. } \\
\text { Semi-domestic. }\end{array}$ \\
\hline Malus domestica Borkh. & Manzano & Rosaceae & $E$ & 6.1 & Gathering crop residues. & Domestic. \\
\hline Azorela monantha Clos & Leña de piedra & Apiaceae & $\mathrm{N}$ & 6.1 & Gathering. & Low degree of human influence. \\
\hline Pinus ssp. * & Pino & Pinaceae & $E$ & 3.0 & Firewood programs. & \\
\hline Salix viminalis $\mathrm{L}$. & Sauce mimbre & Salicaceae & $E$ & 3.0 & Gathering. & Domestic. \\
\hline $\begin{array}{l}\text { Schinus patagonicus (Phil.) I.M. } \\
\text { Johnst. ex Cabrera. }\end{array}$ & Laura & Anacardiaceae & $\mathrm{N}$ & 3.0 & Gathering. & Semi-domestic. \\
\hline Atriplex lampa (Moq.) D. Dietr. & Sampa & Chenopodiaceae & $\mathrm{N}$ & 3.0 & Gathering. & Low degree of human influence. \\
\hline Ephedra ochreata Miers & Silupe & Ephedraceae & $\mathrm{N}$ & 3.0 & Gathering. & Low degree of human influence. \\
\hline Fabiana imbricata Ruiz and Pav. & Palo piche & Solanaceae & $\mathrm{N}$ & 3.0 & Gathering. & Low degree of human influence. \\
\hline $\begin{array}{l}\text { Maihuenia patagonica (Phil.) Britton } \\
\text { and Rose }\end{array}$ & Chupa sangre & Cactaceae & $\mathrm{N}$ & 3.0 & Gathering. & Low degree of human influence. \\
\hline Mulinum spinosum (Cav.) Pers. & Neneo & Apiaceae & $\mathrm{N}$ & 3.0 & Gathering. & Low degree of human influence. \\
\hline Senecio sp. & Charcao & Asteraceae & $\mathrm{N}$ & 3.0 & Gathering. & Domestic. \\
\hline Ulmus minor Mill. & Olmo & Ulmaceae & $E$ & 3.0 & Gathering. & Domestic \\
\hline
\end{tabular}

UC, Use Consensus; N, Native; E, Exotic; *Non-local landscape plants.

the rivers, locally known as "resaque," consisting of a mixture of native and exotic species, which may be used thanks to local knowledge of water pulses. From this landscape mostly native species are obtained ( $88 \%, 15$ species) (Binomial test, $p=0.002$ ) (Figure 3). The exotic species Salix sp. is the most collected.
The landscapes with least human intervention are also widely known and explored by locals, who reported frequenting them since they were children, when they would go out with their parents to gather firewood and do other activities such as checking on the herd. The highest proportion of inhabitants 'cites 


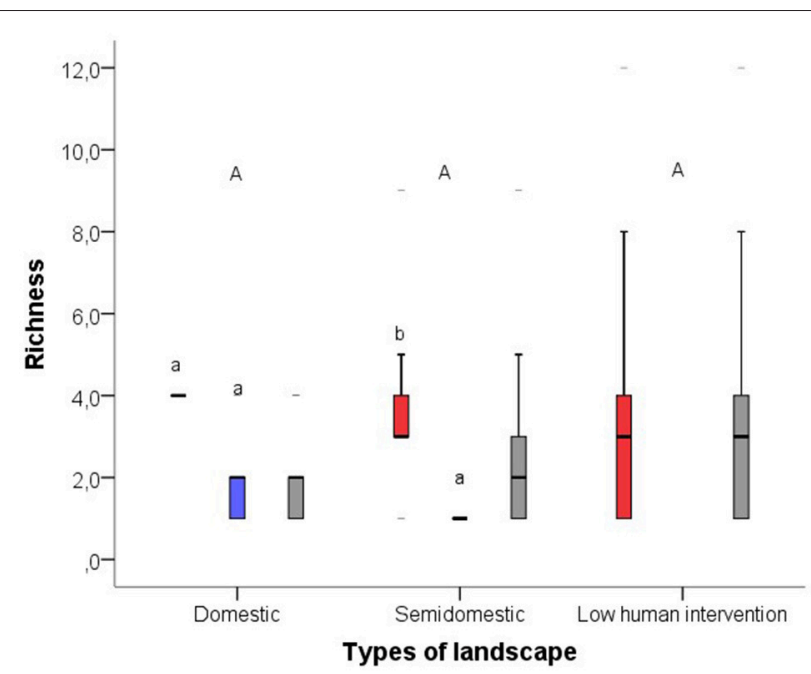

FIGURE 3 | Average richness of combustible species cited by inhabitants according to landscape categories (domestic, semi-domestic and low human intervention) and biogeographic origin. Key: $\boldsymbol{\square}$ Native species; $\boldsymbol{\square}$ Exotic species; Total number. Different letters indicate significant differences.

(47\%) refers to the use of this environment, from which only native species are obtained (Figure 3). Schinus johnstonii is the most collected; according to informants its roots provide very good quality firewood. Nevertheless, they do show concern about its increasing scarcity, as it is slow growing and suffers great pressure of use.

\section{Comparison between Life Forms}

Most species used were shrubs (70\%, 21 species), and were found mainly in semi-domestic and low human intervention landscapes, while trees (30\%, 9 species) were found mostly near watercourses (semi-domestic) or cultivated by man as hedges, for wind protection and other uses in the domestic landscapes. $N$. antarctica and Pinus sp. are trees whose wood constitutes an important part of the firewood used by inhabitants; however, it is not obtained in the local landscape, but is purchased by the truckload or received through state aid programs.

\section{Use Consensus of Species According to Level of Landscape Domestication and Biogeographic Origin}

The three types of landscape were used with the same intensity (Test de Kruskall-Wallis, $p=0.61$ ). Interestingly, the domestic landscape presented a higher average UC $(11.72 \% \pm 3.71)$ than both the semi-domestic landscape $(10.75 \pm 2.49)$, and the landscape with least human intervention $(8.52 \pm 1.78)$ (Figure 4).

Results relating to biogeographic origin also went against our hypothesis, as no differences were found in the use of the different landscapes for the gathering of native (Kruskal-Wallis test $=$ 0.160 , Figure 4) or exotic firewood plants (Kruskall-Wallis test, $p$ $=0.399$, Figure 4). Nevertheless, the average value for UC of the native species is higher in the semi-domestic than in the domestic landscape, and the average UC value for the exotic species is higher in the semi-domestic and domestic areas than in those of low human intervention.

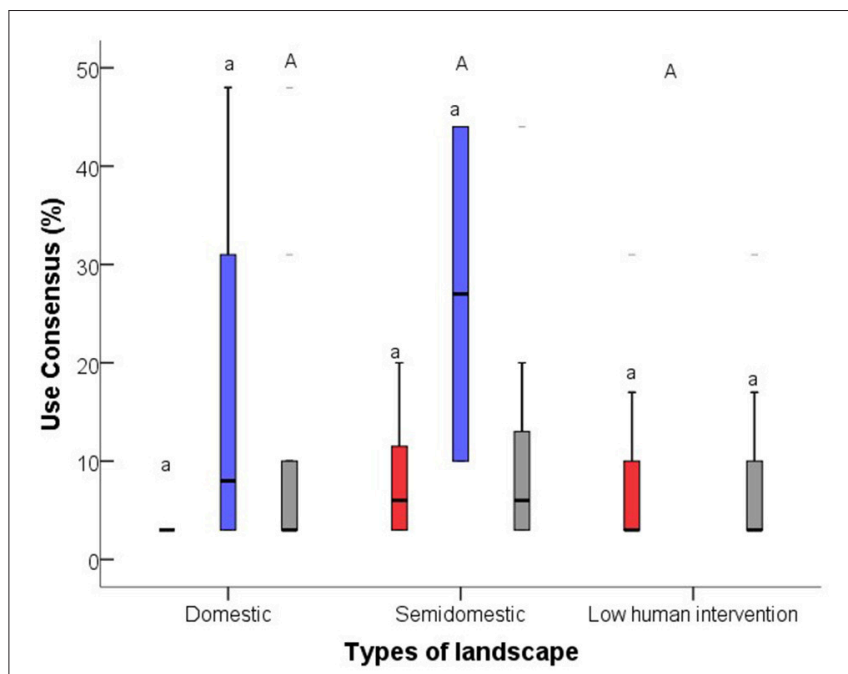

FIGURE 4 | Total and partial average use consensus (UC), according to biogeographic origin of the firewood species in the different categories of landscape (domestic, semi-domestic and low human intervention): Key: $\mathbf{\square}$ UC of native plants; $\mathbf{\square} \cup \mathrm{C}$ of exotic plants; $\mathbf{0}$ Total UC. A: No significant differences to use consensus between different categories of landscape $(p>0.05)$. a: No significant differences to use consensus according to biogeographic origin of the firewood species in each different categories of landscape $(p>0.05)$.

\section{Versatility of Use of Firewood Species}

Of all informants' cites, $71.2 \%$ referred to plants which were used only for firewood (cooking and heating) (Table 2). The remaining cites made reference to firewood species which were also used for other purposes, from two to three different uses (i.e., construction materials, fodder, dye, medicine, food). The species of highest use versatility are exotic: P. alba, Salix sp, Prunus cerasus, and Malus domestica.

\section{Versatility of Use of Firewood Plants According to the Level of Landscape Domestication and Biogeographic Origin}

The average use versatility of the firewood species showed no variation between the different landscapes in terms of their level of domestication (Kruskall-Wallis test, $p=0.19$, Figure 5). Neither did they show significant differences between types of landscape in terms of biogeographic origin (Kruskall-Wallis test $p>0.05$, Figure 5). In the domestic area, $60 \%$ of the species (6 species) are used for multiple purposes, while 4 are used only for fuel ( $40 \%$ of the total), although these differences are nonsignificant (Binomial test, $p=0.75$ ). In the semi-domestic areas, in contrast, fewer of the firewood plants are used for multiple purposes $(18 \%$, 3 species) than those used for fuel alone $(82 \%$, 14 species) (Binomial test, $p=0.013$ ). The landscape with least human intervention follows the same pattern.

In the domestic areas, the UC of multi-use combustible species $(17.2 \% \pm 7.50)$ was higher than the species used exclusively for fuel $(3.4 \% \pm 0)$, although these differences were not significant (Mann Whitney $U$-test, $p=0.11$, Figure 6). The multi-use combustible species with highest UC was $P$. alba (48.3\%). The semi-domestic landscape followed a similar pattern, since the multi-use combustible species $(19.5 \% \pm 12.8)$ 
TABLE 2 | Summary of cases for variables of multinomial logistic model representing the firewood species gathered by the Mapuche communities of Costa del Lepá and Gualjaina

\begin{tabular}{llcc}
\hline Variables & Categories & N & $\begin{array}{c}\text { Percentage of } \\
\text { cites }\end{array}$ \\
\hline DEPENDENT VARIABLE & & \\
Landscape unit & 1. Low human intervention & 84 & 47.5 \\
& 2. Semi-domestic & 59 & 33.3 \\
& 3. Domestic & 34 & 19.2 \\
INDEPENDENT VARIABLES & & 74.0 \\
Biogeographic origin & 1. Native & 131 & 26.0 \\
& 2. Exotic & 46 & 71.2 \\
Use versatility & 1. Exclusively fuel & 126 & 28.8 \\
\hline
\end{tabular}

Frequency represents the total number of plant cites for each sub-category.

presented higher UC than the fuel-only species $(8.9 \% \pm 1.2)$, but without significant differences (Mann Whitney $U$-test, $p=0.59$, Figure 6). Salix sp., a multi-use species, was the most frequently cited (44.8\%).

In contrast, in the low intervention landscape the UC of fuelonly species $(9.6 \% \pm 2.05)$ was higher than the multi-use species $(3.4 \% \pm 0)$, although not significant (Mann Whitney $U$-test, $p=$ 0.15 , Figure 6). Schinus johnstonii (31\%) and N. axillaris (17.2\%), fuel-only species, were the most frequently cited plants.

\section{Continuity of Use of Firewood Species}

Of all the combustible species registered, only three correspond to plants currently out of use $(10.7 \%$ of the total); inhabitants reported using them during their infancy. According to informants, the native shrub species Prosopis denudans var. patagonica, Retanilla patagonica, and Atriplex lampa are not in current use, a fact associated with their lack of regeneration and lack of access to the plants.

Despite the limited nature of their firewood resources, Mapuche communities allow neighbors to have free access to the semi-domestic and low anthropic intervention landscapes for firewood gathering, without establishing previous agreements within the communities to regulate this use. However, some sectors in the region have been appropriated by the previously mentioned livestock companies, which forbid the extraction of firewood plants and are drastically altering provision strategies.

The remaining species have a history of continuous use (11 species; 39.3\%), amongst which S. johnstonii, N. axillaris and Corynabutilon bicolor are worthy of special note, being found mainly in the low anthropic intervention environments; either they have been incorporated gradually (16 species in current use, $50 \%$ del total) due to their environmental (i.e., cultivated species such as $P$. alba, P. cerasus, M. domestica, and Ulmus minor), and/or commercial availability, such as Pinus ssp. and $N$. antarctica. The firewood plants which have been used for a long time have a higher UC $(31.2 \% \pm 6.2)$ than both those recently incorporated $(12.5 \% \pm 5.6)$ and those which are no longer used $(7.3 \% \pm 2.1)(\mathrm{K}-\mathrm{W}$ allis test, $p=0.003)$.
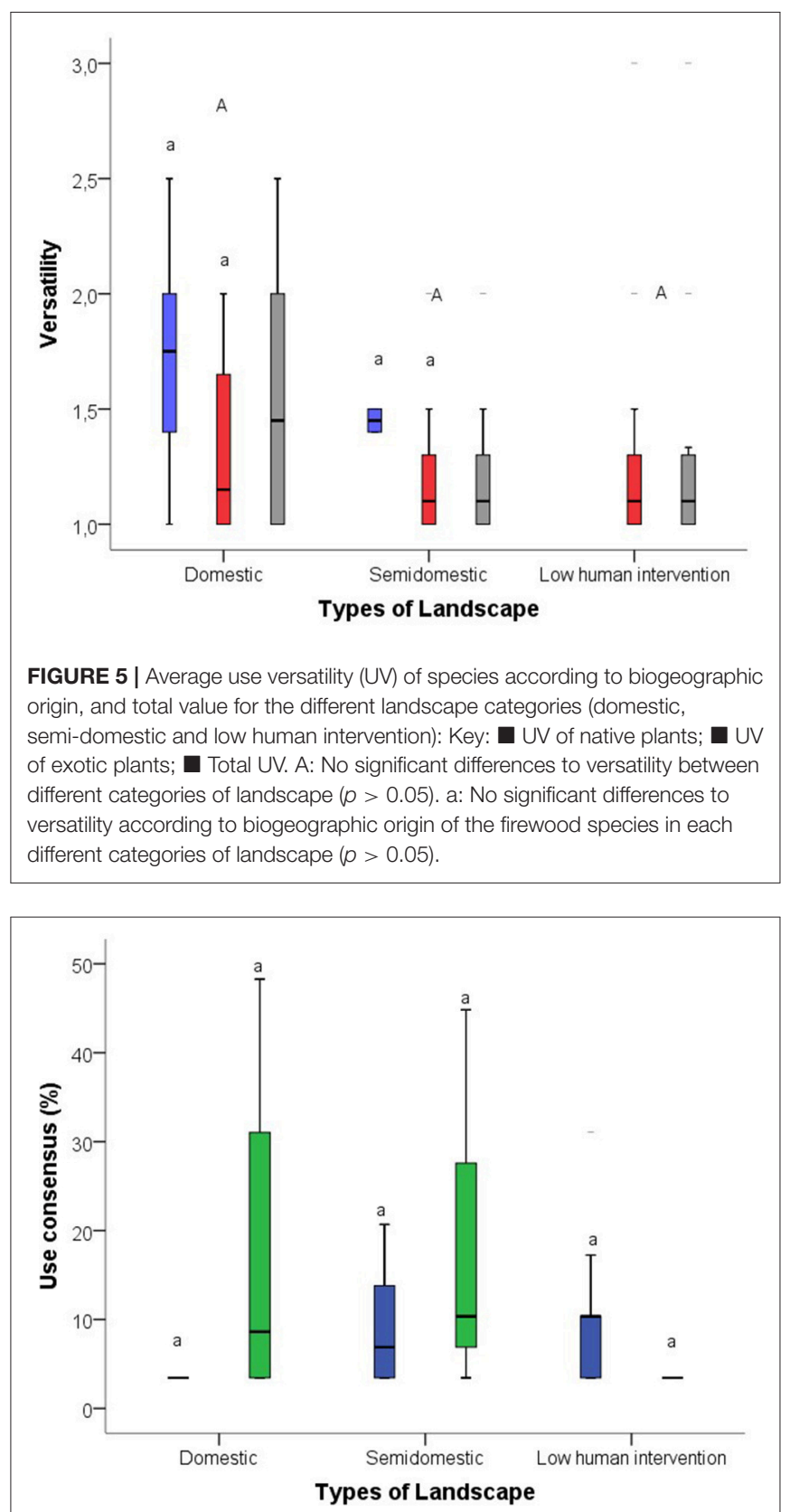

FIGURE 6 | Comparison of use consensus according to versatility of use of firewood species for the different landscape categories (domestic, semi-domestic and low human intervention): Key: $\mathbf{F u e l - o n l y ~ s p e c i e s ; ~}$ Multiple use species. a: No significant differences according to versatility of use of firewood species for the different landscape categories $(p>0.05)$.

\section{Differential Use of the Landscape According to Biogeographic Origin and Use Versatility of Combustible Species}

Descriptions of the variables analyzed and the distribution of all cases are detailed in Table 2 . The model to explain variation in the proportion of plants with different biogeographic origins and use versatility in the landscapes analyzed together was found to be significant $\left(\chi^{2}: 110, d f=4, p<0.05\right)$. Other 
models that considered continuity of use and life form did not give significant results, so these variables were excluded. By means of this multinomial analysis which evaluates the weight of variables as a function of the other variables, it was found that the biogeographic origin of the firewood plants varied for the different classes of landscape $\left(\chi^{2}: 20.6, d f=2, p<0.05\right)$. This result contributes more information than the univariate analysis (Figure 4). In the landscape with low human intervention, the probability of native plants use is 100 times greater in the domestic landscape ( $p<0.05$, Table 3 ). Furthermore, the semidomestic landscape showed no variation in biogeographic origin in relation to the domestic landscape ( $p=0.07$, Table 3$)$. In contrast, for exotic species the patterns are reversed; the domestic areas have 100 times as many exotic plants as those with low human intervention. The use versatility of firewood plants did not vary with the different levels of landscape domestication $\left(\chi^{2}\right.$ : $0.8, d f=2, p=0.66$ ). As was found previously with univariated analysis, the availability of combustible species with greater use versatility does not seem to be associated with domestication of the landscape.

\section{DISCUSSION}

Our results show that the landscapes with a lower level of domestication are not the most intensively used, not in terms of number of species, use intensity or species with higher use versatility. For the two communities living on the Chubut steppe, gathering patterns of firewood plants depend entirely on landscapes with different levels of domestication, which are used in an articulated way. This gathering pattern is dynamic and possibly evolves with the changes that come about in the landscape and other factors such as livestock breeding. All these environments created according to the needs of locals are used in a complementary way, possibly indicating "prudent" (Shaanker et al., 2003) and diversified use of these resources, so that the impact of gathering is distributed across the entire environmental gradient (Cardoso et al., 2017). This reflects an integrated concept of the landscape, as has been widely documented for different traditional peoples in Argentina (Crivos et al., 2004; Pirondo and Keller, 2014). In other words, the landscape units present spatial continuity in response to ecological gradient, type of management and the multiple interconnections generated by the inhabitants and their domestic animals, all of which is accompanied by global exploitation (Capparelli et al., 2011; Molares and Ladio, 2012, 2014).

The communities of Costa del Lepá and Gualjaina obtain in total 28 different firewood species, a richness similar to that registered by Cardoso et al. (2012), who recorded 27 species in other rural zones on the Patagonian steppe. This richness is the result of diverse use of the landscape and the integration of new supply strategies, such as purchase and social welfare plans (Cardoso et al., 2013). The species are shared little between environments, considering the intentional addition of exotic and new species in the most domesticated landscape, mainly for firewood purposes. However, the low diversity of species in these environments (10 species) coincides with domestication patterns that tend toward a reduction in the number of species, monoculture and specialization of species (Amico, 2002). The three types of environment analyzed showed no significant differences in the proportions of native and exotic species gathered, indicating that gathering pressure is shared between the different landscapes. Nevertheless, the multinomial analysis showed that the probability of collecting native plants is 100 times higher in environments with low domestication, while the reverse is true for exotic species. The inhabitants have incorporated a

TABLE 3 | Parameters estimated from the multinomial regression.

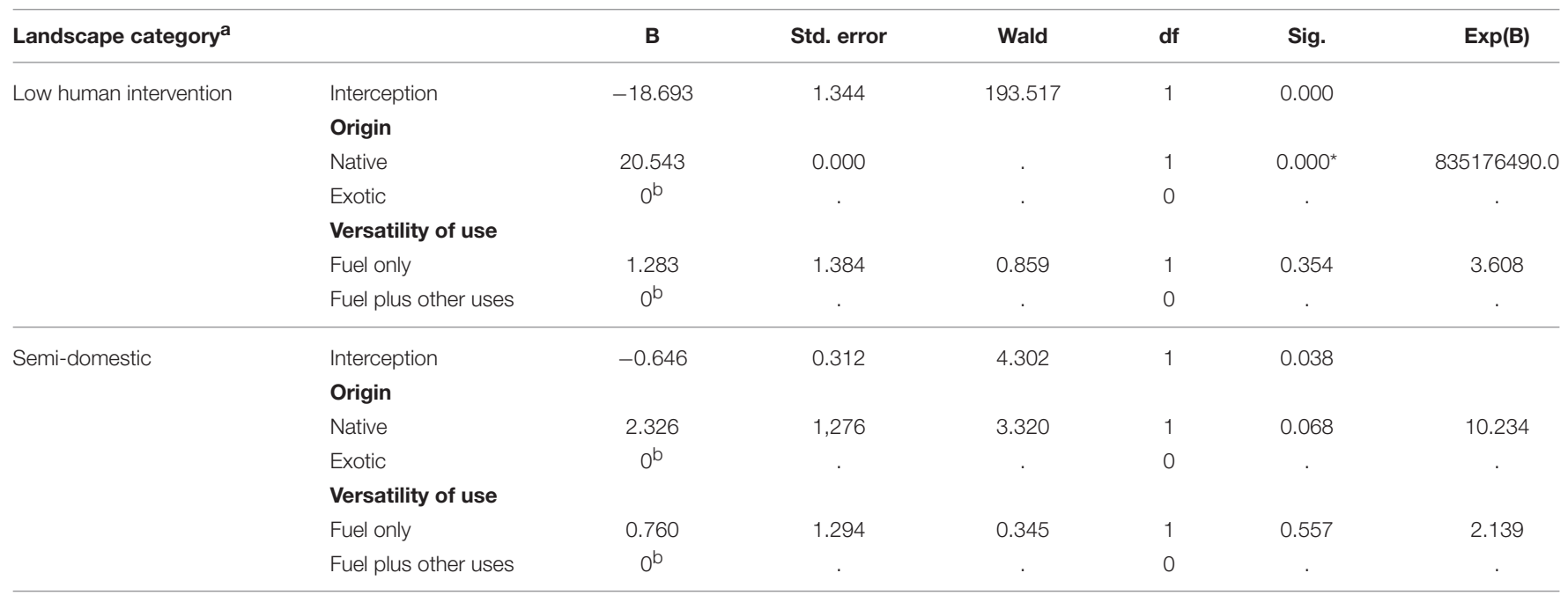

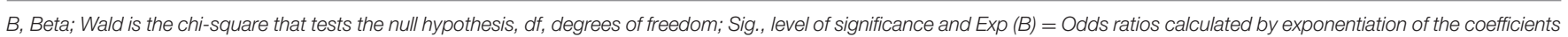
(the probability that an event will happen in relation to the probability it will not).

"The reference category is: Domestic landscape.

${ }^{b}$ This parameter is established as zero since it is redundant.

*This symbol indicates significant differences. 
high proportion of exotic species through cultivation, in addition to those species which have begun to grow in the wild. This could be favored by the decreasing availability of native resources and the strong influence of external government organizations which provide technical support that promotes the incorporation of exotic resources (Eyssartier et al., 2013). The use of exotic species in domestic landscapes in Patagonia and other regions of the world has been highlighted by several authors to be a local solution to various needs, since in general they are easily available, fast growing, and more tolerant than native species (Eyssartier et al., 2009; Dos Santos et al., 2010; Richeri et al., 2013; Rovere et al., 2013), in addition to complementing native species, covering new needs, and diversifying the offer of useful plants (Albuquerque, 2006; Medeiros, 2013; Ladio and Albuquerque, 2014).

The semi-domesticated landscape, which includes mainly river valleys, with an intermediate level of human intervention, was also a significant site for the gathering of firewood. In these environments the species richness of native plants gathered is higher than that of exotics, although the latter are the most used. The more frequent use of the exotic species may be associated with their abundance, accessibility and quality, as observed in other studies (Albuquerque et al., 2009; Cardoso et al., 2012). One notable example of this is Salix sp., an exotic species of rapid growth that quickly colonizes and becomes established on most Patagonian riverbanks, in many cases displacing the native species S. humboltiana, and competing successfully for resources and suitable regeneration sites (Bozzi et al., 2014).

In contrast, the landscapes where there had been relatively little anthropic intervention presented the greatest number of cites for native firewood plants (100 times more than the most domesticated environment). Previous investigations carried out in similar environments in Patagonia have highlighted the important use of native species for firewood, compared to exotics (Cardoso et al., 2012). Schinus johnstonii is the most frequently gathered resource in this landscape. The cultural importance of this species over time has been documented in archaeobotanical studies and in recent work in the region, highlighting this species' characteristics of high calorific value and long-lasting embers (Ancibor and Pérez de Micou, 1995; Cardoso et al., 2013; Morales et al., 2017).

The results also indicate that there is no variation in pattern of use of the landscape in terms of use versatility, and that in general terms the combustible plants are not very versatile, possibly due to their fuel uses (heating and cooking) being prioritized in the interview. Even so, it must be mentioned that the firewood plants, as well as providing energy, are a source of animal fodder, are used in making shelters for the animals and in construction, as also found by Cardoso et al. (2012) and Morales et al. (2017). These authors highlight the fact that the introduction of rapidly growing exotic firewood plants in peri-domestic areas increases the richness of uses of the flora, revealing mechanisms that improve inhabitants' self-sufficiency.

It is interesting to note the dynamics of use of the different landscape areas over time. According to informants, during their infancy the semi-domestic and low anthropic intervention environments were of more importance for plant gathering than they are now, given their higher offer of species with high calorific value. At the present time, the extraction of firewood is affected by the work of large livestock companies, as well as the increasing problem of desertification due to overgrazing, amongst other factors, which cause damage to the soil and plant cover. These phenomena gradually configure a new landscape, thus generating the need for new strategies to obtain supplies (Marconetto, 2006).

Analysis of the interviews reveals that historically, the purchase of firewood species was infrequent in the studied communities, as was the use of gas. It has been recorded that half the population now buys firewood plants, mainly $N$. antarctica, which comes from the Sub-Antarctic Forest, and is one of the most commonly used and most commercially exploited species (Arre et al., 2015). The current tendency to purchase firewood, as a provision strategy, has also been observed in other rural communities (Ramos et al., 2008; Cardoso et al., 2012); in this way the factor of uncertainty in the availability of these subsistence resources, as conceptualized by Blancas et al. (2014), is decreased.

Together with the preferential use of species adapted to the disturbances typical of these environments (e.g., fires, overgrazing) (Morales et al., 2017), this suggests an articulated, dynamic system in which processes of climate and sociopolitical change (decrease in precipitation, mineral extractivism, etc.), flora and populations all coevolve. Thus, complementary use of the landscape, selection of species that grow quickly after harvesting and innovation in supply strategies (purchase), understood as local responses to the problem of change (Ladio, 2017), promote faster recuperation of the landscape and woody species, decreasing uncertainty and increasing biocultural resilience (Ladio, 2017; Morales et al., 2017). For example, some informants revealed that since many people have started buying firewood, regeneration of native plants such as Retanilla patagonica has been observed. This moment in the collective memory of the studied populations marks the beginning of an indirect process of promotion of the availability of this species, so that it can be used in the future; this is, therefore, management that will promote domestication of the environment.

\section{CONCLUSIONS}

Firewood gathering has always been stigmatized and associated with practices considered as destructive, and carried out by poor communities. In our case study visibilization of the firewood gathering practice from the perspective of landscape domestication allows us to reveal more complex, integral processes. Although native plants are much used and obtained from environments with a low level of domestication, inhabitants do not seem to concentrate their efforts on those environments alone. Medium and high domestication level landscapes contribute exotic (and native) plants which play a substantial role, alleviating use pressure on native species, and while this cannot prevent over exploitation, it does minimize it. The continuity of use of wood for combustible purposes is also favored, guaranteeing a supply of this resource, fundamental for subsistence, and an important component of the locals' lifestyle. 
Complementary use of the landscape is the underlying logic, but the incipient domestication of species present in the totally domesticated environments is also an interesting aspect that should be studied in more depth. The growth of these plants (10 species) is being encouraged with irrigation, thermal and wind protection, pruning, the adding of organic material from home composting, etc., which generates greater production of firewood and reduces impact in terms of extraction of native species.

In the arid region of Patagonia significant effects are expected in the coming years, in association with global climate change. These changes will no doubt affect the communities whose subsistence depends on their close bond with the landscape and its resources (Rabassa, 2010). Within this scenario it is essential to review government strategies and conservation plans, which are always top-down. The inclusion of bottom-up perspectives on the subject of firewood is necessary in order to find solutions that take local management and cosmologies into account in an inclusive way (Ladio, 2017). Our empirical information reveals that the inhabitants of Patagonia are creating new environments

\section{REFERENCES}

Albuquerque, U. (2006). Re-examining hypotheses concerning the use and knowledge of medicinal plants: a study in the Caatinga vegetation of NE Brazil. J. Ethnobiol. Ethnomed. 2:30. doi: 10.1186/1746-4269-2-30

Albuquerque, U., De Sousa Araujo, T., Ramos, M., Do Nascimento, V., De Lucena, R., Monteiro, J., et al. (2009). How ethnobotany can aid biodiversity conservation: reflections on investigations in the semi-arid region of NE Brazil. Biodivers. Conserv. 18, 127-150. doi: 10.1007/s10531-0089463-8

Alburquerque, U., Paiva de Lucena, R., and Cruz da Cunha, L. (2010). Métodos e técnicas na pesquisa Etnobiológica y Etnoecológica. Recife: Nuppea.

Amico, I. (2002). Viverización y cultivo de álamos y sauces en el NO de Chubut. Buenos Aires: Boletín de divulgación INTA.

Ancibor, E., and Pérez de Micou, C. (1995). Archaeological record of the Patagonian Steppe. J. Ethnobiol. 15, 189-200.

Arre, J., Molares, S., Ladio, A., and Kutschker, A. (2015). Etnobotánica de las plantas leñateras y su circuito comercial en una ciudad de la patagónica. Gaia Sci. 9, 41-48. doi: 10.21707/gs.v9i3.27245

Barrera-Bassols, N., and Toledo, V. (2005). Ethnoecology of the Yucatec Maya: symbolism, knowledge and management of natural resources. J. Lat. Am. Geogr. 4, 9-40. doi: 10.1353/lag.2005.0021

Berkes, F. (2004). Rethinking community-based conservation $\backslash$ rRepensando la conservación basada en comunidades. Conserv. Biol. 18, 621-630. doi: 10.1111/j.1523-1739.2004.00077.x

Berkes, F., Colding, J., and Folke, C. (2000). Rediscovery of traditional ecological knowledge as adaptive management. Ecol. Appl. 10, 1251-1262. doi: 10.1890/1051-0761(2000)010[1251:ROTEKA]2.0.CO;2

Berkes, F., and Davidson-Hunt, I. (2006). Biodiversity, traditional management systems, and cultural landscapes: examples from the boreal forest of Canada. Int. Social Sci. J. 58, 35-47. doi: 10.1111/j.1468-2451.2006. 00605.x

Blancas, J., Pérez-Salicrup, D., and Casas, A. (2014). Evaluando la incertidumbre en la disponibilidad de recursos vegetales. Gaia Sci. 8, 137-160. doi: 10.21707/gs. v8i2.22419

Boillat, S., Serrano, E., Rist, S., and Berkes, F. (2013). The importance of place names in the search for ecosystem-like concepts in indigenous societies: an example from the Bolivian Andes. Environ. Manage. 51, 663-678. doi: 10.1007/s00267-012-9969-4

Bozzi, J., Marchelli, P., and Gallo, L. (2014). Sauce criollo: una especie nativa amenazada en Patagonia. Presencia 25, 29-33. with richness and versatility of use, and seeking new alternatives in the face of firewood scarcity, through landscape domestication.

\section{AUTHOR CONTRIBUTIONS}

$\mathrm{AL}$ and SM conceived of the study, designed the questionnaires, participated in data analysis and performed statistical analysis. DM carried out questionnaires among the Mapuche communities, analyzed the tales, performed statistical analysis and drafted the manuscript. The three authors read and approved the final manuscript.

\section{ACKNOWLEDGMENTS}

Our thanks are due to the inhabitants of the Costa del Lepá and Gualjaina communities for their friendly disposition, generous help, and for sharing their knowledge and experience. We are also grateful to the two reviewers whose suggestions helped improve this work substantially. This research was supported by PIP 0466 of CONICET.

Cabrera, A. (1976). Regiones fitogeográficas argentinas. Enciclopedia Argentina de Agricultura y Jardinería, Tomo II Fs. 1st Edn. Buenos Aires: ACME. Bs. As. Argentina, 1-85.

Capparelli, A., Hilgert, N., Ladio, A., Lema, V., Llano, C., Molares, S., et al. (2011). Paisajes culturales de Argentina: pasado y presente desde las perspectivas etno- botánica y paleoetnobotánica. Rev. Asoc. Argent. Ecol. Paisaje 2, 67-79.

Cardoso, B., and Ladio, A. (2011). Forestación peridoméstica en Patagonia y conocimiento ecológico tradicional: un estudio de caso. Sitient. Ciênc. Biol. 11, 321-327. doi: 10.13102/scb110

Cardoso, B., Ladio, A., Dutrus, S., and Lozada, M. (2015). Preference and calorific value of fuelwood species in rural populations in northwestern Patagonia. Biom. Bioen. 81, 514-520. doi: 10.1016/j.biombioe.2015.08.003

Cardoso, B., Ladio, A., and Lozada, M. (2012). The use of firewood in a Mapuche community in a semi-arid region of Patagonia, Argentina. Biom. Bioen. 46, 155-164. doi: 10.1016/j.biombioe.2012.09.008

Cardoso, B., Ladio, A., and Lozada, M. (2013). Fuelwood consumption patterns and resilience in two rural communities of the northwest Patagonian steppe, Argentina. J. Arid Environ. 98, 146-152. doi: 10.1016/j.jaridenv.2012.09.013

Cardoso, M. B., Lozada, M., and Ladio, A. (2017). Niche breadth and redundancy: useful indices to analyse fuelwood use in rural communities. J. Arid Environ. 145, 52-59. doi: 10.1016/j.jaridenv.2017.05.007

Casas, A., Camou, A., Otero-Arnaiz, A., Rangel-Landa, S., Cruse-Sanders, J., Solís, L., et al. (2014). Manejo tradicional de biodiversidad y ecosistemas en Mesoamérica: el Valle de Tehuacán. Invest. Ambient. Cien. Polít. Públ. 6, 23-44.

Casas, A., Otero-Arnaiz, A., Pérez-Negrón, E., and Valiente-Banuet, A. (2007). In situ management and domestication of plants in Mesoamerica. Ann. Bot. 100, 1101-1115. doi: $10.1093 / \mathrm{aob} / \mathrm{mcm} 126$

Casas, A., Rangel-Landa, S., Torres, I., Peréz-Negrón, E., Solís, L., Parra, F., et al. (2008). "In situ management and conservation of plant resources in the Tehuacán-Cuicatlán Valley, México: an ethnobotanical and ecological approach," in Current Topics in Ethnobotany, eds U. P. De Albuquerque and M. Alves-Ramos (Kerala: Research Signpost), 1-25.

Castro, V., Aldunate, C., and Varela, V. (2012). Paisajes Culturales de Cobija, Costa de Antofagasta, Chile. Revista de Antropología $N^{\circ}$ 26, 2do Semestre, 2012, 97-128.

Chan, Y. H. (2005). Biostatistics 305. Multinomial logistic regression. Singapore Med. J. 46, 259-269.

Chettri, N., and Sharma, E. (2007). Firewood value assessment: a comparison on local preference and wood constituent properties of species from a trekking corridor, West Sikkim, India. Curr. Sci. 92, 1744-1747. 
Correa, M. N. (1971). Flora patagónica. Parte VII. Compositae. Buenos Aires: Colección Científica del INTA. Bs. As, 451.

Correa, M. N. (1978). Flora Patagónica. Gramineae. Tomo 8 Parte 3. Buenos Aires: Colección Científica del INTA. Bs. As.

Correa, M. N. (1984). Flora patagónica. Parte IVa. Dicotiledóneas Dialipétaleas (Salicaceae a Cruciferae). Buenos Aires: Colección Científica del INTA. Bs. As., 559.

Crivos, M., Mart, R., Pochettino, L., Remorini, C., Saenz, C., and Mart, R. (2004). Nature and domestic life in the Valle del Cuñapirú (Misiones, Argentina): reflections on Mbyá Guaraní ethnoecology. Agric. Human Values 21, 111-125. doi: 10.1023/B:AHUM.0000029400.88032.a2

Davidson-Hunt, I. J., and Berkes, F. (2003). Learning as you journey: Anishinaabe perception of social-ecological environments and adaptive learning. Conserv. Ecol. 8:5. doi: 10.5751/ES-00587-080105

Dos Santos, A., Duarte da Rocha, C., and Bergallo, H. (2010). Native and exotic species in the urban landscape of the city of Rio de Janeiro, Brazil: density, richness, and arboreal deficit. Urb. Ecosyst. 13, 209-222. doi: $10.1007 /$ s11252-009-0113-z

Encuesta Complementaria de Pueblos Indígenas (ECPI) (2007). Complementaria del Censo Nacional de Población, Hogares y Viviendas. 2001, 20042005. Disponible en: Available online at: www.indec.gov.ar (Consultado en noviembre de 2007).

Eyssartier, C., Ladio, A., and Lozada, M. (2009). Uso de plantas medicinales cultivadas en una comunidad semi-rural de la estepa patagónica. Blacpma 8, 77-85. Available online at: http://udg.redalyc.org/articulo.oa?id= $85611769004>$

Eyssartier, C., Ladio, A., and Lozada, M. (2013). Traditional horticultural and gathering practices in two semi-rural populations of Northwestern Patagonia. J. Arid Environ. 97, 18-25. doi: 10.1016/j.jaridenv.2013.05.008

Fernández-Llamazares, Á., Díaz-Reviriego, I., Guèze, M., Cabeza, M., Pyhälä, A., and Reyes-García, V. (2016). Local perceptions as a guide for the sustainable management of natural resources: empirical evidence from a small-scale society in Bolivian Amazonia. Ecol. Soc. 21:2. doi: 10.5751/ES-08092-210102

Greider, T., and Garkovich, L. (1994). Landscapes: the social construction of nature and the environment. Rural Sociol. 59, 1-24. doi: 10.1111/j.1549-0831.1994.tb00519.x

Guber, R. (2006). La etnografía, Método, Paisaje Silvestre y Reflexividad. Buenos Aires: Grupo editorial Norma. Bs. As, 146.

Haber, A. (2006). Una arqueología de los oasis puneños. Domesticidad, interacción $e$ identidad en Antofalla, primer y segundo milenios d. C. Córdoba: Jorge Sarmiento Editor/Universitas libros.

Höft, M., Barik, S. K., and Lykke, A. M. (1999). Quantitative Ethnobotany. Applications of Multivariate and Statistical Analyses in Ethnobotany. Paris: Division of Ecological Sciences, UNESCO; People and Plant Working Paper.

Instituto Nacional de Estadística y Censos (2010). Available online at: www.indec. gob.ar/nivel2_default.asp?id_tema $=2 \&$ seccion $=P$

ISE (2006). International Society of Ethnobiology Code of Ethics. Available online at: http://ethnobiology.net/code-of-ethics

Kareiva, P., Watts, S., McDonald, R., and Boucher, T. (2007). Domesticated nature: shaping landscapes and ecosystems for human welfare. Science 316, 1866-1869. doi: $10.1126 /$ science. 1140170

Ladio, A. (2017). Ethnobiology and research on Global Environmental Change: what distinctive contribution can we make? Ethnobiol. Conserv. 6, 1-8. doi: 10.15451/ec2017-07-6.7-1-8

Ladio, A., and Albuquerque, U. (2014). The concept of hybridization and its contribution to urban ethnobiology. Ethnobiol. Conserv. 3, 1-9. doi: 10.15451/ec2014-11-3.6-1-9

Ladio, A., and Lozada, M. (2003). Comparison of edible wild plant diversity used and foraging strategies in two aboriginal communities of NW Patagonia. Biodiv. Conserv. 12, 937-951. doi: 10.1023/A:1022873725432

Ladio, A., and Lozada, M. (2004). Patterns of use and knowledge of wild edible plants from distinct ecological environments: a case study of a Mapuche community from NW Patagonia. Biodivers. Conserv. 13, 1153-1173. doi: 10.1023/B:BIOC.0000018150.79156.50

Ladio, A., Lozada, M., and Weigandt, M. (2007). Comparison of traditional wild plant knowledge between aboriginal communities inhabiting arid and forest environments in Patagonia, Argentina. J. Arid Environ. 69, 695-715. doi: 10.1016/j.jaridenv.2006.11.008
Ladio, A., and Molares, S. (2013). Evaluating traditional wild edible plant knowledge among teachers of Patagonia: patterns and prospects. Learn. Individ. Differ. 27, 241-249. doi: 10.1016/j.lindif.2013.04.002

Ladio, A., and Molares, S. (2014). El paisaje Patagónico y su gente. Ecología e Historia Natural de la Patagonia Andina: Un cuarto de siglo de Investigación en Biogeografía, Ecología y Conservación, 205-223. Buenos Aires: Ed. Fundación de Historia Natural Félix de Azara.

Lema, V. (2014). Criar y ser criados por las plantas y sus espacios en los Andes septentrionales de Argentina. Espacialidades altoandinas. Nuevos aportes desde la Argentina. Tomo I: Miradas hacia lo local, lo comunitario y lo doméstico, 301-338.

Lins Neto, E., Peroni, N., Casas, A., Parra, F., Aguirre, X., Guillén, S., et al. (2014). Brazilian and Mexican experiences in the study of incipient domestication. J. Ethnobiol. Ethnomed. 10:33. doi: 10.1186/1746-4269-10-33

Marconetto, M. (2006). "La gente, la leña, el monte," in El Modo de Hacer las Cosas. C. Pérez de Micou comp. (Buenos Aires: FFyL. UBA).

Medeiros, P. (2013). Why is change feared? Exotic species in traditional pharmacopoeias. Ethnobiol. Conserv. 2, 1-5. doi: 10.15451/ec2013-8-2. 3-1-05

Mereb, M. (1990). Caracterización climatológica de los valles superior y medio del río Chubut. Dirección general de estudios y proyectos. Hidrometeorológico principal. Provincia del Chubut: Ministerio de economía, obras y servicios públicos.

Miller, A., and Davidson-Hunt, I. (2010). Fire, agency and scale in the creation of aboriginal cultural landscapes. Hum. Ecol. 38, 401-414. doi: $10.1007 /$ s10745-010-9325-3

Molares, S., and Ladio, A. (2009). Ethnobotanical review of the Mapuche medicinal flora: use patterns on a regional scale. J. Ethnopharmacol. 122, 251-260. doi: $10.1016 /$ j.jep.2009.01.003

Molares, S., and Ladio, A. (2012). Mapuche perceptions of Andean Nothofagus forests and their medicinal plants: a case study from a rural community in Patagonia, Argentina. Biodivers. Conserv. 21, 1079-1093. doi: 10.1007/s10531-012-0241-2

Molares, S., and Ladio, A. (2014). Medicinal plants in the cultural landscape of a Mapuche-Tehuelche community in arid Argentine Patagonia: an eco-sensorial approach. J. Ethnobiol. Ethnomed. 10:61. doi: 10.1186/1746-4269-10-61

Morales, D., Molares, S., and Ladio, A. (2017). A biocultural approach to firewood scarcity in rural communities inhabiting arid environments in Patagonia (Argentina). Etnobiol. Conserv. 6:12. doi: 10.15451/ec2017-08-6.12-1-17

Phillips, O., and Gentry, A. (1993). The useful plants of Tambopata, Peru: I statistical hypothesis test with a new quantitative. Econ. Bot. 47, 15-32. doi: $10.1007 / \mathrm{BF} 02862203$

Pirondo, A., and Keller, H. (2014). Aproximación al paisaje a través del conocimiento ecológico. Etnoecologica. 10, 59-69.

Rabassa, J. (2010). El cambio climático global en la Patagonia desde el viaje de Charles Darwin hasta nuestros días. Rev. Asoc. Geol. Argent. 67, 139-156. Avalaible online at: http://www.scielo.org.ar/scielo.php?script=sci arttext\&pid=S0004-48222010000400014\&lng=es\&nrm=iso

Ramos, M., Medeiros, P., Almeida, A., Feliciano, A., and Albuquerque, U. (2008). Use and knowledge of fuelwood in an area of Caatinga vegetation in NE Brazil. Biom. Bioen. 32, 510-517. doi: 10.1016/j.biombioe.2007.11.015

Richeri, M., Ladio, A., and Beeskow, A. (2013). Conocimiento tradicional y autosuficiencia: la herbolaria rural en la Meseta Central del Chubut (Argentina). Bol. Latinoam. Caribe Plant. Med. Aromáti. 12, 44-58. Avalaible online at: http://artificialwww.redalyc.org/articulo.oa?id=85625709006>

Rovere, A., Molares, S., and Ladio, A. (2013). Plantas utilizadas en cercos vivos de ciudades patagónicas: aportes de la etnobotánica para la conservación. Ecol. Aust. 23, 165-173. Avalaible online at: http://www.scielo.org.ar/scielo. php?script=sci_arttext\&pid=S1667-782X2013000300005\&lng=es\&nrm=iso >

Sedrez dos Reis, M., Ladio, A., and Peroni, N. (2014). Landscapes with Araucaria in South America: evidence for a cultural dimension. Ecol. Soc. 19:43. doi: 10.5751/ES-06163-190243

Shaanker, R. U., Ganeshaiah, K. N., Krishnan, S., Ramya, R., Meera, C., Aravind, N. A., et al. (2003). "Livelihood gains and ecological cost of NTFP dependence: assessing the roles of dependence, ecological knowledge and market structure in three contrasting human and ecological settings in south India," in The International Conference on Rural Livelihoods, Forests and Biodiversity (Bonn), $1-25$. 
Tabuti, J. (2007). The uses, local perceptions and ecological status of 16 woody species of Gadumire Sub-county, Uganda. Biodivers. Conserv. 16, 1901-1915. doi: 10.1007/s10531-006-9097-7

Tabuti, J., Dhilliona, S., and Lyea, K. (2003). Firewood use in Bulamogi County, Uganda: species selection, gathering and consumption patterns. Biom. Bioen. 25, 581-596. doi: 10.1016/S0961-9534(03)00052-7

Tiwari, K., Tynsong, H., and Lynser, M. (2010). Forest management practices of the tribal people of Meghalaya, north-east India. J. Trop. For. Sci. 22, 329-342.

Toledo, V. M., Ortiz-Espejel, B., Cortés, L., Moguel, P., and Ordoñez, M. J. (2003). The multiple use of tropical forests by indigenous peoples in Mexico: a case of adaptive management. Conserv. Ecol. 7:9. doi: 10.5751/ES-00524070309

Washington, H. (2013). Human Dependence on Nature: How to Help Solve the Environmental Crisis. London: Earthscan.
Zuloaga, F., and Morrone, O. (1999). Flora del Cono Sur. Catálogo de las Plantas Vasculares. Buenos Aires: Instituto de Botánica "Darwinion". Available online at: www.darwin.edu.ar/proyectos/floraargentina/fa.htm

Conflict of Interest Statement: The authors declare that the research was conducted in the absence of any commercial or financial relationships that could be construed as a potential conflict of interest.

Copyright (c) 2017 Morales, Molares and Ladio. This is an open-access article distributed under the terms of the Creative Commons Attribution License (CC BY). The use, distribution or reproduction in other forums is permitted, provided the original author(s) or licensor are credited and that the original publication in this journal is cited, in accordance with accepted academic practice. No use, distribution or reproduction is permitted which does not comply with these terms. 